\section{Quantitative Analyses of the Spore Coat Protein in the Cell Extracts of Bacillus subtilis*1}

Short Paper

Because of the inertness of spore coat protein, it is very difficult to determine the quantity of it. In the course of the investigation on the biosynthesis of spore coat protein, we have made quantitative analyses of the spore coat protein in the cell extracts during sporulation of Bacillus subtilis by use of the polymerized antibody.

$B$. subtilis 3610 (ATCC 6051) was used as the wildtype sporulating strain. The strains 110NA(spoOA) and 11T(spoIV) were used as the asporogenic mutants. Cultures were grown in the Schaeffer liquid nutrient broth sporulation medium ${ }^{1)}$ supplemented with 0.1 $\mu \mathrm{Ci} / \mathrm{m} l$ of ${ }^{14} \mathrm{C}$-labelled phenylalanine or serine. Cells were harvested at approximately one doubling time before and at the intervals of every $1 \mathrm{~h}$ after the end of exponential growth. The cells were disintegrated by sonication. The extracts were centrifuged in a refrigerated centrifuge at $10,000 \mathrm{rpm}$ for $10 \mathrm{~min}$. The supernatant fluids were again centrifuged at $18,000 \mathrm{rpm}$ for $30 \mathrm{~min}$ and frozen at $-20^{\circ} \mathrm{C}$.

Antiserum to the spore coat protein was prepared and polymerized as described previously ${ }^{2,8}$.

Immunological binding assay for spore coat protein was done as follow: with the polymerized antibody concentration held constant $(0.5 \mathrm{ml})$, various volumes of cell extracts ( $0.1 \mathrm{mg}$ cell equivalent) were added to each assay tube and the total volume was adjusted to $1.0 \mathrm{~m} /$ by adding saline. The antigen-antibody mixture was incubated for $30 \mathrm{~min}$ at $37^{\circ} \mathrm{C}$ and then stood overnight at $5^{\circ} \mathrm{C}$. Each sample was then centrifuged and washed three times with saline. The pellet fractions were assayed for labelled spore coat protein by calculating specific radioactivity of proteins.

Rifampicin $(10 \mu \mathrm{g} / \mathrm{ml})$ was added to the culture at $t_{0}$ stage of sporulation.

The results are shown in Fig. 1. In the sporulating strain (wild-type), the spore coat protein appeared in the cell extracts at $t_{2}$ stage of sporulation. After that, the synthesis of the spore coat protein increased rapidly until $t_{4}$ stage. The concentration of the spore coat protein was about $40 \mu \mathrm{g} / \mathrm{mg}$ cells at $\mathrm{t}_{4}$ stage. There was no difference between the ${ }^{14} \mathrm{C}$-phenylalanine labelled cells and the ${ }^{14} \mathrm{C}$-serine labelled cells. After $t_{4}$ stage the concentration of the spore coat protein in the cell extracts decreased. This phenomenon may be due to the conversion of spore coat protein from the soluble form to the insoluble form. A similar result was reported with the spore coat protein of $B$. cereus $\mathrm{T}^{4}$.

When rifampicin was added to the culture at $t_{0}$ stage, the appearance of the spore coat protein in the cell extracts was completely inhibited.

This is probably due to the non-specific absorption of proteins to the polymerized antibody ${ }^{32}$.

(Received July 18, 1978)

*1 Bacillus subtilis の胞子形成過程飞抢ける細胞抽出 液中の spore coat タンパク量の剆定.

*2 内田有恒・閏田元: 京都大学袈学部水産学科.

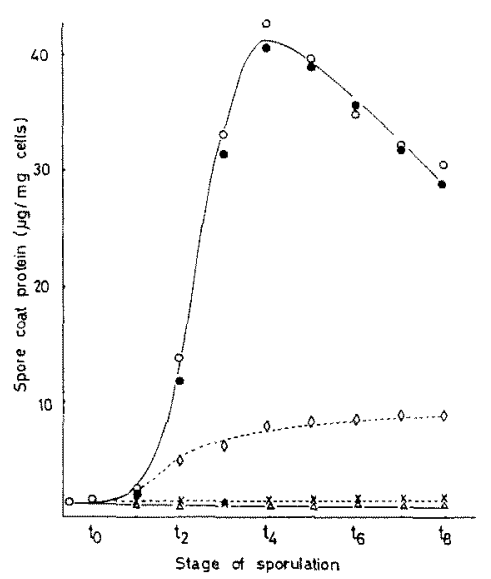

Fig. 1. Biosynthesis of spore coat protein during sporulation of $B$. subtilis 3610 (ATCC 6051) and its asporogenic mutants.

O, 3610 (calculated with ${ }^{14} \mathrm{C}$-L-phenylalanine); -, 3610 (calculated with ${ }^{14} \mathrm{C}$-L-serine); $\triangle, 3610$ (rifampicin was added at $\left.t_{0}\right) ; \times, 110 \mathrm{NA}(\mathrm{spoOA})$; $\diamond, 11 \mathrm{~T}$ (sporv).

The 110NA(spoOA) mutant did not synthesize spore coat protein. On the other hand, 11T(spoIV) mutant synthesized a small quantity (about $8 \mu \mathrm{g} / \mathrm{mg}$ cells) of the spore coat protein. In strain $11 \mathrm{~T}$ the synthesis of the spore coat protein began as early as in the wild type strain, but after the stage $t_{2}$ a remarkable increase of the spore coat protein was not observed. This result indicates that some of the late stage mutants of $B$. subtilis were able to produce small quantities of the spore coat protein in a soluble form in the mother cells, and that they were not able to deposit the spore coat protein on the surface of spores $2,3,5$.

These results suggest that the biosynthesis of the spore coat protein begins at almost the same time of synthesis of alkaline phosphatase, a sporulation specific enzyme associated with stage $11^{0)}$.

Aritsune UCHIDA ${ }^{* 2}$ and Hajime KADOTA*2

Laboratory of Microbiology, Department of Fisheries, Faculty of Agriculture, Kyoto University, Kyoto, Japan

\section{References}

1) P. Schaeffer, J. Muliet, and J. P. Aubert: Proc. Nat. Acad. Sci. U.S.A., 54, 707-711 (1965).

2) A. UCHIDA, H. KADOTA, and P. SchaEfFER: $J$. Bacteriol., 126, 1342-1343 (1976).

3) A. UChida and H. Kadota: Agr. Biol. Chem., 40, 1349-1354 (1976).

4) D. Horn, A.I. Aronson, and E.S. Golub: $J$. Bacteriol., 113, 313-321 (1973).

5) D. A. Woon: Biochem. J., 130, 505-514 (1972).

6) A. R. GleNN and J. G. Coote: Biochem. J., 152, 85-89 (1975). 